\title{
Kroatiens lange vej \\ til medlemskab af EU
}

\section{Niels-Ulrik Amdal}

I lyset af EU-landenes problemer med at ratificere forfatningstraktaten og EU's manglende legitimitet i store dele af befolkningen skal Kroatien ikke forvente, at der vil være plads til at slække på optagelseskravene - og de er i forvejen høje

Champagneflaskerne var lagt på køl op til den 17. marts 2005. Dagen var udset til en festdag, hvor Kroatien ville få grønt lys til at indlede optagelsesforhandlinger med EU. Men sådan skulle det ikke gå. Propperne blev i flaskerne, fordi Kroatiens manglende samarbejde med Den Internationale Krigsforbryderdomstol vedrørende det tidligere Jugoslavien (ICTY) i Haag fik EU til at aflyse festlighederne til kroaternes store ærgrelse.

Allerede i 2003 havde Kroatien ellers fået stillet et EU-medlemskab i udsigt, hvis landet kunne "take the necessary steps for full cooperation with the ICTY and ... that the remaining indictee be located and transferred to the Hague as soon as possible". For den kroatiske premierminister, Ivo Sanader, havde forløbet indtil da været en triumf i at vise omverdenen, at Kroatien kunne leve op til EU's krav til medlemskab. Men triumfen var til at overse, da EU ikke ville anerkende, at Kroatien udviste fuld samarbejdsvilje så længe den kroatiske hærgeneral og nationalhelt Ante Gotovina fortsat var på fri fod.

Men selvom festen blev aflyst, var der alligevel grund til optimisme. EU's udenrigsministre besluttede nemlig at godkende den aftale, der definerer rammerne for selve optagelsesforhandlingerne. Rammeaftalen blev allerede præsenteret af Kommissionen i januar i år, og selvom den i sig selv ikke er nogen garanti for optagelsesforhandlinger, 
har den stor politisk symbolværdi, fordi den signalerer, at EU er positiv over for de reformtiltag, der sker i Kroatien.

Godkendelsen af rammeaftalen betyder, at forhandlingerne kan gå $\mathrm{i}$ gang umiddelbart efter, at EU beslutter sig for det, og man undgår derved yderligere forsinkelser. At EU's udenrigsministre godkendte rammeaftalen var et klassisk eksempel på EU's evne til at indgå kompromisser mellem medlemsstaterne og give en gulerod til et ansøgerland for fortsat at motivere til reformer.

Afvisningen af at indlede selve optagelsesforhandlingerne var derimod meget klar. Luxembourgs udenrigsminister, Jean Asselborn, hvis land sidder i formandsstolen i første halvår af 2005, pointerede, at fuldt samarbejde med Haag er en klar forudsætning for forhandlinger.

Ungarn, Østrig, Italien og Slovenien forsøgte ellers ihærdigt at overbevise EU-kollegaerne om den kroatiske velvilje til at udlevere krigsforbryderanklagede og om alle de reformtiltag, Kroatien i øvrigt har gjort. Ungarns premierminister, Ferenc Gyurcsany, mente eksempelvis ikke det var retfærdigt at straffe et helt land for én persons forbrydelser.

Forklaringen på at det netop er disse lande, der ønskede en start for optagelsesforhandlinger, skal findes i de nære regionale, historiske og $ø$ konomiske forbindelser landene har med Kroatien.

\section{Historisk proces}

Kroatiens ansøgning om medlemskab er et led i en historisk regionaliserings- og europæiseringsproces. Landene på det vestlige Balkan er, om end langsomt, så i det mindste i gang med at overvinde regionens politiske kriser og krige og orientere sig mod et Europa baseret på demokrati og stabilitet.

I Thessaloniki i juni 2003 vedtog Det Europæiske Råd at "det er op til de vestlige Balkanlande selv at sette tempoet $i$ deres fortsatte tilncermelse til $E U$, og at tempoet vil afhenge af de resultater, som de enkelte lande opnår med hensyn til gennemforelse af reformer og dermed overholdelsen af de kriterier, der blev fastlagt af Det Europeiske Råd $i$ København i juni 1993, samt konditionaliteten i forbindelse med stabiliserings- og associeringsprocessen".

Forudsætningerne i stabiliseringsog associeringsprocessen blev fastsat af Det Europæiske Råd tilbage i 1997. Heraf fremgår utvetydigt nødvendigheden af samarbejde med ICTY og fortsat udbygning af det regionale samarbejde.

Forudsætningerne er videreført i den stabiliserings- og associeringsaftale, der er indgået med Kroatien i 2001. Det er med andre ord op til Albanien, Bosnien \& Hercegovina, Makedonien, Serbien \& Montenegro og Kroatien selv at tilpasse sig de politiske og økonomiske kriterier og EU's acquis communautaire. At det er Kroatien, der er førende i denne 
proces er ikke nogen tilfældighed, men resultatet af en målrettet $o g$ til tider indenrigspolitisk kontroversiel indsats for at distancere sig fra sin kommunistiske og senest nationalistiske fortid.

\section{Speciel historie}

Den kroatiske historie er speciel på flere måder. Ironisk nok blev det nemlig Titos kommunister og ikke de nationale kroater, der indtog en afgørende rolle i dannelsen af den kroatiske nation. Under Jugoslaviens føderale statssystem blev de kroatiske områder samlet og kom for første gang under den samme centrale administration. I de første mange år af Titos styre var der imidlertid ikke plads til, eller for den sags skyld accept af, Kroatiens selvstændige regionale samarbejde.

Efter Titos brud med Stalin begyndte den føderale stat at decentralisere til republikkerne i stadig større omfang, og Jugoslavien begyndte at udvikle sin egen kommunistiske samfundsmodel. Decentraliseringen var en konsekvens af den spirende officielle tanke om selvstyrende socialisme, der tog udgangspunkt i en afstandstagen fra det marxistisk-leninistiske dogme og lod sig inspirere af folk som Proudhon og Blanc.

Den selvstyrende socialisme, der kendetegnede tiden under Tito, gav Kroatien gode forudsætninger, da selvstændigheden blev en realitet den 25. juni 1991. Men det var først efter Tudjmanns død i 1999, at der for alvor skete betydelige ændringer i Kroatien. Under ledelse af den daværende premierminister, Racan, blev der sat yderligere skub i implementeringen af Dayton fredsaftalen, det regionale samarbejde og forsoningsprocessen. Det var også Racan, der gjorde medlemskab af EU til sin regerings hovedprioritet.

Den prioritet har skiftende regeringer holdt fast ved, og både den nuværende præsident, Stjepan Mesic, og premierminister Ivo Sanader har offentlig tilkendegivet at EU-medlemskabet er en strategisk målsætning for Kroatien.

I november 2003 blev der afholdt valg til parlamentet, Sabor. Ivo Sanader fra Tudjmanns højreorienterede parti Den Kroatiske Demokratiske Union (HDZ) vandt valget og dannede en regeringskoalition med Det Kroatiske Socialliberale Parti (HSLS), Det Demokratiske Centrum (DC), Det Kroatiske Pensionistparti (HSU) samt repræsentanter fra mindretallene.

Sanader har brugt mange kræfter på at overbevise kritikere om, at partiet ikke længere er et nationalistisk orienteret parti, men at det har undergået en transformationsproces hen imod et mere traditionelt konservativt parti. HDZ har da også bevist, at partiet er stærkt indstillet på at omstille sig til et demokratisk parti med en pro-europæisk overbevisning. Udtalelser fra partiet, mens det var i opposition, sår imidlertid tvivl 
om, hvorvidt denne opfattelse deles af alle i partiet.

Kroatiens bestræbelser på at harmonisere sin lovgivning med EU-retten er imidlertid fortsat ufortrødent. I løbet af de seneste år er der blevet vedtaget love på det økonomiske område, herunder inden for valutaog selskabsretten, og det arbejdsretlige område. Den videre udfordring ligger $i$ at sikre, at lovgivningen gennemføres og myndighederne har tilstrækkelig med ressourcer og vilje til at håndhæve den.

Korruption er ligeledes et problem, og til trods for væsentlige forbedringer de seneste år, er der fortsat brug for en vedvarende indsats for at bekæmpe den.

\section{Mindretal og menneskerettigheder}

For at leve op til EU's krav om minoritetsbeskyttelse har Kroatien indført en række bestemmelser i forfatningen, der skal garantere respekten for menneskerettighederne og mindretallenes rettigheder. Landet er medlem af Europarådet og har ratificeret FN's menneskerettighedskonventioner. Organisations- og forsamlingsfriheden er ligeledes sikret i forfatningen. Til trods for forfatningsændringerne anser EU Kroatiens behandling af minoriteter for at være problematisk.

På trods af at ejendomsretten anerkendes i forfatningen, skrider processen med tilbagelevering af ejendomme, der blev konfiskeret under det jugoslaviske kommunistiske styre og krigen, kun meget langsomt frem. Under krigshandlingerne fra 1991-1995 flygtede over 300.000 etniske serbere. I dag er over en tredjedel vendt tilbage, men ikke til deres oprindelige hjem, for de er i mange tilfælde overtaget af kroatere, der flygtede fra Bosnien. Lovgivningen på området sikrer også kun efterkommere i første led denne mulighed eller alternativt en kompensation. Situationen forværres yderligere af, at de tilbagevendende har meget svært ved at finde sig et arbejde.

Den kroatiske befolkningssammensætning udgøres af 16 forskellige nationale mindretal. Det største mindretal er serbere med $4,5 \%$, efterfulgt af bosnier med $0,47 \%$ og italienere, ungarere, albanere og slovenere med hver omkring 0,3\%. Ifølge de officielle statistikker udgør romanerne $0,21 \%$, men det reelle tal vurderes som betydeligt højere.

I december 2002 vedtog parlamentet det retsgrundlag, der skal sikre de nationale mindretals rettigheder. Mindretallene garanteres indtil 8 repræsentanter i det nationale parlament og sikres også repræsentation i retsvæsenet og den statslige og kommunale forvaltning.

Det store serbiske mindretal i Donau-regionen er yderligere tilgodeset i Erdut-aftalen, der sikrer proportional repræsentation i politistyrken og retsvæsenet samt ret til mindretalsskoler. 
Til trods for de gode hensigter oplever mange, at de bliver chikaneret af myndighederne. Der er eksempler på, at folk ikke kan få udbetalt pension, fordi de har været væk fra arbejdsmarkedet i en årrække - mens de var på flugt under krigshandlingerne.

\section{Domstolen og Gotovina}

Krigsforbryderdomstolen har indtil videre rejst tiltale mod 32 kroater, hvoraf hovedparten er fra Bosnien \& Hercegovina. Den 8. juni 2001 blev der rejst tiltale in absentia mod den kroatiske hærgeneral Ante Gotovina. Ifølge anklageskriftet står han tiltalt for krigsforbrydelser under Operation Storm i 1995, hvor soldater under hans kommando stod bag drab på 150 civile serbere og fordrivelse af over 150.000 .

Samarbejdet med krigsforbryderdomstolen blev formelt realiseret med forfatningsloven i april 1996. Både i statutten for ICTY og Romstatutten for Den Internationale Straffedomstol findes begrebet "kommandoansvar". Kroatien anerkender begrebet, men den nuværende straffelov erklærer ikke eksplicit kommandoansvar for strafbart. Straffeloven blev ellers ændret i juli 2003 for at gøre kommandoansvar ansvarspådragende, men forfatningsdomstolen har efterfølgende ophævet loven, fordi den ikke var vedtaget med det fornødne stemmeflertal.
På trods af juridiske spidsfindigheder er Kroatiens samarbejde med ICTY forbedret betydeligt gennem de senere år. Det interne retsopgør er efterhånden også blevet intensiveret, og over 500 er blevet idømt straffe ved de nationale domstole. Hovedparten af dem, der er overført til Haag, var under krigen en del at den berygtede paramilitære enhed "Herceg-Bosna".

Hvorvidt de kroatiske myndigheder gør tilstrækkeligt for at pågribe og udlevere Ante Gotovina er et spørgsmål, der kan svares både ja og nej til, afhængig af om man spørger i Zagreb eller i Bruxelles. Den kroatiske regering påstår stædigt, at den gør alt hvad der er i dens magt for at finde manden, der er entrebilletten til EU. "Gotovina er ikke i Kroatien, men rejser frit rundt $i$ andre lande på sit franske pas, som han har erhvervet sig efter at have gjort tjeneste i den franske fremmedlegion", lyder det officielle svar fra Zagreb, der således forsøger at placere en del af ansvaret i Paris.

Hvorvidt der er hold i påstanden er i sagens natur vanskeligt at afklare, men det er bemærkelsesværdigt, at det først var få uger før EU's udenrigsministermøde i marts, at Kroatien indefrøs Gotovinas konti og begyndte at tilbageholde hans militærpension.

En anden episode, der indikerer at der er centralt placerede folk, der ikke ønsker, at generalen pågribes, var afsløringen af en stort anlagt ef- 
terretningsoperation mellem den britiske og den kroatiske efterretningstjeneste. Operation "cash", der havde til formål at anholde generalen, blev afsløret, og de pågældende agenters identitet blev lækket til medierne.

\section{Økonomisk politik}

Hvis Gotovina befandt sig i Haag, var Kroatien i dag godt på vej til et fuldt europæisk medlemskab. De økonomiske forudsætninger, der er en del af Københavnskriterierne, anses nemlig for gode, og Europa-Kommissionen har anerkendt Kroatien for at sikre en stabil makroøkonomisk udvikling med relativ lav inflation.

Krigen og overgangen fra plan$ø$ konomi til markedsøkonomi i begyndelsen af 1990'erne havde ellers store samfundsøkonomiske konsekvenser. Arbejdsløsheden steg og udenlandske investeringer i landet var beskedne, ikke mindst fordi privatiseringsprocessen tilgodeså tidligere betroede medarbejdere og folk centralt placeret i systemet.

Kroatiens udgangspunkt i omstillingsprocessen var dog det mest gunstige blandt de tidligere jugoslaviske republikker. Det var den næstrigeste republik, infrastrukturen var god, der var en veludbygget turistindustri og veletablerede kontakter til Vesten. Landet var industrialiseret før det blev kommunistisk, og det undgik en centraldirigeret planlægning i kommunistisk stil.
Det juridiske grundlag for privatiseringen findes i Omdannelsesloven fra $1991 \mathrm{og}$ Privatiseringsloven fra 1993, der omfattede over 3000 statsejede selskaber, dog med undtagelse af centrale forsyningsselskaber, og selskaber med afgørende betydning for infrastruktur.

Privatiseringen fortsatte op igennem 1990'erne, og i de seneste år er den politiske fokusering ændret fra en generel makroøkonomisk stabilisering til finanspolitisk konsolidering og strukturtilpasning. Formålet er ikke overraskende at skabe øget vækst og øge konkurrenceevnen. Den økonomiske og finansielle politik støttes af aftaler med EU, IMF og strukturtilpasningslån fra Verdensbanken.

\section{Regionalt samarbejde}

Efter at Kroatien blev selvstændig i 1991, var der en velbegrundet frygt for, at Kroatien ville udvikle sig til et semi-totalitært regime med en nationalistisk politik. Det viste sig også at være tilfældet i en årrække, hvor regionalt samarbejde blev afløst af krig og ufred.

Men efter Tudjmans død i 1999 og det efterfølgende regimeskifte er forbindelserne til naboerne, og ikke mindst til Bosnien \& Hercegovina de seneste år blevet markant forbedret. Forholdet var tidligere bl.a. kendetegnet ved, at Zagreb førte en parallel-politik til kroater i "føderationen Bosnien \& Hercegovina”, men i dag 
er det alene centraladministrationen i Sarajevo der samarbejdes med.

Kroatien spiller en proaktiv rolle $\mathrm{i}$ regionen. Ud over at være en central del af stabiliserings- og associeringsaftalen er Kroatien også engageret i mindre kendte fora som det Adriatisk-ioniske initiativ med Italien, Slovenien og Ungarn; det Sydøsteuropæiske samarbejdsinitiativ; AlpeAdriaterinitiativet og Donau-kommissionen. I 2003 underskrev Kroatien et aftalememorandum om etableringen af et regionalt elmarked for Sydøsteuropa og året før en rammeaftale om Sava-flodbækkenet med Slovenien, Bosnien \& Hercegovina og Serbien \& Montenegro.

Forholdet til Makedonien er blandt de bedste, og landene har indgået over 20 bilaterale aftaler. Tilsvarende er relationerne til Slovenien tætte, og Kroatien har bibeholdt det gode naboforhold efter Sloveniens indtræeden i EU den 1. maj 2004. Forholdet til Albanien er præget af en politisk dialog på højt niveau, der bl.a. har udmøntet sig i en frihandelsaftale og en afskaffelse af visumpligten.

Forholdet til Italien er af særlig betydning, for Italien er Kroatiens største udenlandske investor og handelspartner. De ellers gode bilaterale økonomiske forbindelser påvirkes imidlertid af uafklarede politiske spørgsmål. $90 \%$ af de italienere, der var bosiddende i Jugoslavien, forlod landet mellem 1943 og 1947, og staten lod deres ejendomme nationali- sere. Italiens krav på disse ejendomme har ført til, at det kroatiske parlament i 2002 har vedtaget en lov om afnationalisering. Loven giver udenlandske statsborgere ret til kompensation eller tilbagelevering, såfremt der er indgået bilaterale aftaler derom. Kroatien og Italien er ved at indgå sådanne aftaler.

\section{Næste skridt}

På udenrigsministrenes møde i marts og det efterfølgende møde i Det Europæiske Råd blev man enige om at nedsætte en taskforce, der skal overvåge Kroatiens bestræbelser på at leve op til EU's krav om fuldt samarbejde med ICTY.

Taskforcen ledes af EU's udenrigspolitiske chef, Javier Solana, og består af repræsentanter fra det nuværende og de kommende formandskaber for EU samt embedsmænd fra Kommissionen. Ud over det nuværende formandsland, Luxembourg, er både England og $\emptyset_{\text {strig }}$ repræsenteret i gruppen. Gruppen skal løbende afrapportere til EU's udenrigsministre, og på baggrund af disse rapporter og rapporteringen fra FN's chefanklager Carla del Ponte træffer de en endelig beslutning om, hvornår Kroatien er klar til optagelsesforhandlinger.

Kroatien kan på mange områder betegnes som et land de andre tidligere jugoslaviske republikker kan lære af. Men selvom der er foretaget mange positive handlinger fra $\mathrm{Za}$ - 
grebs side, er der fortsat lang vej til det forjættede medlemskab af EU. Og vejen er ikke blevet kortere efter det franske nej til forfatningstraktaten den 29. maj i år.

Kroaterne skal heller ikke gøre sig forhåbninger om, at Tony Blair vil se mere pragmatisk på ansøgningen, for briterne var en af de skarpeste kritikere af Kroatiens manglende velvilje til at pågribe Gotovina. Sammenholdt med helt andre og langt vigtigere problemer omkring ratifikationen af forfatningstraktaten og EU's manglende legitimitet blandt store dele af EU's befolkning skal Kroatien heller ikke forvente, at der vil være plads til at slække på kravene til Sanader og hans regering.
Måske gør Zagreb bedst i at lade champagnen blive i køleskabet og koncentrere sig om at pågribe Gotovina - og så satse på, at Østrig som formandsland i første del af 2006 vil give grønt lys for optagelsesforhandlingerne.

Niels-Ulrik Amdal er cand.scient.pol fra Københavns Universitet og M.A. $i$ International Conflict Analysis fra University of Kent at Canterbury. Artiklen er skrevet inden Carla Del Pontes møde med den kroatiske premierminister Ivo Sanader den 2. - 3. juni 2005. 